Abstracta Iranica Abstracta Iranica

Revue bibliographique pour le domaine irano-aryen

Volume 31 | 2011

Comptes rendus des publications de 2008

\title{
"I Missionari Teatini in Georgia nel secolo XVII ", in : Mirella Galetti, ed., Medici, Missionari, Musicisti e militari italiani attivi in Persia, Impero ottomano ed Egitto. Quaderni di Oriente Moderno, LXXXVIII/6, 2008, p. 15-23.
}

Florence Hellot

\section{OpenEdition}

Édition électronique

URL : http://journals.openedition.org/abstractairanica/39351

DOI : 10.4000/abstractairanica.39351

ISSN : 1961-960X

Éditeur :

CNRS (UMR 7528 Mondes iraniens et indiens), Éditions de l'IFRI

Édition imprimée

Date de publication : 15 mai 2011

ISSN : 0240-8910

Référence électronique

Florence Hellot, « «I Missionari Teatini in Georgia nel secolo XVII », in : Mirella Galetti, ed., Medici, Missionari, Musicisti e militari italiani attivi in Persia, Impero ottomano ed Egitto. Quaderni di Oriente Moderno, LXXXVIII/6, 2008, p. 15-23. », Abstracta Iranica [En ligne], Volume 31 | 2011, document 142, mis en ligne le 11 octobre 2012, consulté le 26 septembre 2020. URL : http://journals.openedition.org/ abstractairanica/39351 ; DOI : https://doi.org/10.4000/abstractairanica.39351

Ce document a été généré automatiquement le 26 septembre 2020.

Tous droits réservés 
«I Missionari Teatini in Georgia nel secolo XVII », in : Mirella Galetti, ed., Medici, Missionari, Musicisti e militari italiani attivi in Persia, Impero ottomano ed Egitto. Quaderni di Oriente Moderno, LXXXVIII/6, 2008, p. 15-23.

Florence Hellot

Carlos Alonso relate dans un bref article les péripéties de deux missionnaires théatins envoyés en Géorgie par la Propagande en 1626. Ils arrivent en 1628 à Gori d'où ils écrivent au pape et décrivent le christianisme géorgien tels qu'ils le perçoivent. Deux nouveaux missionnaires sont envoyés en 1630, ils arrivent en 1632 et gagnent l'Inde en 1635. D'autres théatins viendront à leur tour en Géorgie où ils restent jusqu'à la fin du $\mathrm{XVII}^{\mathrm{e}}$ s., même si des capucins implantent à leur tour une mission en Géorgie. Cet épisode, rempli de ferveur missionnaire, est une page intéressante de l'histoire des missions. Il est plus difficile à utiliser pour retrouver l'histoire de la Géorgie.

INDEX

Thèmes : 4.2.1. Safavides et Qâjârs 
AUTEURS

FLORENCE HELLOT

Mondes iranien et indien - Paris 